\title{
METABOLIC PROFILES DURING LACTATION PERIOD IN COWS
}

\author{
SHIMAA A. ABD EL RAHIM ${ }^{1}$; HASSAN Y.A.E. MAHMOUD ${ }^{2}$; \\ MAHMOUD MOHAMED ARAFA ${ }^{3}$ and ADEL E.A. MOHAMED ${ }^{2}$ \\ ${ }^{1}$ Animal Health Research Institute, Sohag, \\ ${ }^{2}$ Fac. of Vet. Med. South Valley University \\ ${ }^{3}$ Animal Health Research Institute, Dokki, Giza
}

Received: 25 February 2019; Accepted: 30 April 2019

\begin{abstract}
This study conducted using 40 healthy lactating mixed breed cows aged 1.8-4 years from the date of 1-10-2018 to 1-1-2019. These cows selected from Sohag Governorate; 40 cows reared on small farms feed on balanced ration; 20 cows from them were at the first time of parturition, 10 cows were at the second time of parturition and 10 cows were at the third time of parturition. 10 cows used as a control animals brought from farmers houses and feed on unbalanced food. Blood and milk samples collected during three stages of lactation (first, second and third month of lactation). On each serum sample insulin, liver enzymes (SGOT, SGPT and ALP), total bilirubin, kidney function tests (urea, creatinine and uric acid), some minerals includes (Ca, phosphorus, $\mathrm{Cl}, \mathrm{Na}$, and $\mathrm{K}$ ), some heavy metals include ( $\mathrm{Cu}, \mathrm{Fe}$, lead, cadmium and $\mathrm{Se}$ ), some antioxidants include (GSH, CAT and SOD), some hormones include (TSH in serum and milk leptin hormone) and glucose level were measured. A significant effect of the lactation stages were observed on SGOT, SGPT, urea, creatinine, Na, Ca, phosphorus, $\mathrm{Cl}, \mathrm{K}, \mathrm{Cu}, \mathrm{Fe}$, leptin, TSH, GSH, CAT, SOD, glucose, insulin, while there were no significant differences during the three lactation stages on serum ALP, total bilirubin, uric acid and Se.
\end{abstract}

Key words: Dairy Cows - Transition Period - Minerals - Antioxidants - Hormones

\section{INTRODUCTION}

Dairy animals are an important source of animal protein in Egypt. It considered as main source of the food supply in the form of milk, meat (FAO, 2009) and leather (Sarwer et al., 2009).

Lactation stage causes different variation in concentrations of blood metabolites in dairy cows (Yaylak et al., 2009). Lactation phases affect significantly the metabolic profile and so the variation recorded during different physiological phases is expected during the dairy cow production cycle (Smith and Risco, 2005). During the first stage of lactation, mammary gland activity increased results in energy deficiency and increased lipomobilization from body reserves (Arfuso et al., 2016).

During lactation, mammary gland secretory cells utilize $80 \%$ of the blood circulating metabolites for synthesis of milk, depending on the speed of infiltration of precursors of milk compounds (i.e. free amino acids, glucose and fatty acids). All animals

Corresponding author: Dr. Adel E.A. Mohamed E-mail address: adel.mohamed@vet.svu.edu.eg Present address: Fac. of Vet. Med. South Valley University require minerals such as calcium $(\mathrm{Ca})$, and phosphorus (P) for reproduction, growth and lactation, which often affect specific requirements, and contributes as catalytic components of enzymes or regulate several mechanism involved just in pregnancy and lactation (Samardzija et al., 2011).

The level of iron at first month of lactation was less than its level at second month of lactation (Hussain et al., 2001). There was non-significant change in the level of leptin hormone in the first month of lactation when compared to its level in second and third month of lactation (Accorsi et al., 2005). The level of uric acid, SOD, CAT and GSH in the first month of lactation was less than its level at second month of lactation (Pintea et al., 2006).

There was non-significant change in total bilirubin level at first month of lactation when compared to the second month of lactation furthermore non-significant change in calcium and creatinine level (Piccione et al., 2012). The level of ALP in the first month of lactation less than its level at second and third month of lactation (Abdulkareem, 2013).

The level of chloride, potassium and phosphorus in first month of lactation not significant changed when 
compared to its level at second and third month of lactation while, the level of sodium at first month of lactation was less than its level at second month of lactation (Nozad et al., 2014). The level of selenium in the first month of lactation was more than its level at second and third month of lactation (Cong and Xiao., 2016). Fiore et al. (2018) said that the level of SGOT at first month of lactation more than its level at second month and at third month while, the urea level at first month of lactation less than its level at second and third month of lactation and reported that the level of insulin and SGPT in lactating buffaloes at first month of lactation less than its level at second month of lactation, there was non-significant change in the level of TSH at first month of lactation when compared to its level at second and third month of lactation. The level of glucose at first month of lactation was less than its level at second month of lactation (Kalasariya et al., 2017).

\section{MATERIALS AND METHODS}

This study conducted using 40 healthy lactating mixed breed cows aged 1.8-4 years from the date of 1-10-2018 to 1-1-2019. These cows selected from Sohag Governorate; 40 cows reared on small farms feed on balanced ration; 20 cows from them were at the first time of parturition, 10 cows were at the second time of parturition and 10 cows were at the third time of parturition. 10 cows used as a control animals brought from farmers houses and feed on unbalanced ration.

The studied cows divided into 3 groups that fed on balanced ration ( $\mathrm{B}$ at first month of lactation, $\mathrm{C}$ at second month of lactation and $\mathrm{D}$ at third month of lactation. While, the control group $\mathrm{A}$ fed on unbalanced ration.

The main components of the ration of healthy dairy cows and hazard control animals illustrated in (table 1and 2).

Table 1: The main components of balanced ration.

\begin{tabular}{cc}
\hline Component & Amount (kg) in 1 ton of feed \\
\hline Corn & 625 \\
Bran & 250 \\
Soya meal & 100 \\
Mineral mixture & 5 \\
Vitamin & 2.5 \\
NaCl & 12.5 \\
Lime stone & 5 \\
\hline
\end{tabular}

Table 2: The main components of unbalanced ration.

\begin{tabular}{cc}
\hline Component & Amount (kg) in 1 ton of feed \\
\hline Bran & 550 \\
Rice hay & 350 \\
Alfa alfa & 100 \\
\hline
\end{tabular}

Jugular blood samples collected in plain tubes for blood serum biochemistry. The blood was allowed to clot and centrifuged, then clear blood serum was separated and stored at $-20{ }^{\circ} \mathrm{C}$ until analyzed and whey milk sample for leptin hormone analysis.

The separated sera used for detection of some liver enzymes, kidney function tests, glucose and antioxidants by using of test kits supplied by Spectrum Egyptian company of biotechnology, Diamound diagnostic company and Biodiagnostic company, Egypt and by the using of (CECIL 3000 SERIES scanning spectrophotometer).
Serum minerals and some heavy metals by using of atomic absorption (SensAA GBC Scientific Equipment) according to (A.O.A.C., 2015).

Insulin, TSH and leptin hormone by using of ELISA according to (A.O.A.C., 2015) by coating the plate with a capture antibody, then sample is added, and any antigen present binds to capture antibody. Detecting antibody is added, and binds to antigen, and then enzyme-linked secondary antibody which is specific to the first antibody is added, and binds to the detecting antibody. Finally substrate is added, and is 
converted by enzyme to detectable colored form which could be measured by ELISA plate reader.

\section{Statistical analysis}

The obtained data statistically analyzed after the methods described by (Snedecor and Cochran, 1980) analysis of variance, least significant difference and correlation matrix also done by statistical package for social science (SPSS) computer program and ANOVA test.

\section{RESULTS}

In the present study we measured some liver function tests include (SGOT, SGPT, ALP and Total bilirubin) by using spectrophotometer, the result revealed that the mean values were $(59.2 \mathrm{u} / \mathrm{ml}, 36 \mathrm{u} / \mathrm{ml}, 125.9$ $\mathrm{u} / \mathrm{ml}, 1.02 \mathrm{mg} / \mathrm{dl}$ ) respectively in animals feed on unbalanced ration, while in animals feed on balanced ration in the $1^{\text {st }}$ month of lactation were $(41.3 \mathrm{u} / \mathrm{ml}$, $38.6 \mathrm{u} / \mathrm{ml}, 121.9 \mathrm{u} / \mathrm{ml}, 0.83 \mathrm{mg} / \mathrm{dl}$ ) respectively, in the $2^{\text {nd }}$ month of lactation were $(48.4 \mathrm{u} / \mathrm{ml}, 36.3 \mathrm{u} / \mathrm{ml}$, $123.2 \mathrm{u} / \mathrm{ml}, 0.92 \mathrm{mg} / \mathrm{dl}$ ) respectively, in the $3^{\text {rd }}$ month of lactation were $(48 \mathrm{u} / \mathrm{ml}, 36.5 \mathrm{u} / \mathrm{ml}, 123.3 \mathrm{u} / \mathrm{ml}$, $0.84 \mathrm{mg} / \mathrm{dl}$ ) respectively.

In addition to ,we measured some kidney function tests include (Urea, Creatinine and Uric acid) by using spectrophotometer, the result revealed that the mean values were $(35.2 \mathrm{mg} / \mathrm{dl}, 1.19 \mathrm{mg} / \mathrm{dl}, 4.99$ $\mathrm{mg} / \mathrm{dl}$ ) respectively in animals feed on unbalanced ration, while in animals feed on balanced ration in the $1^{\text {st }}$ month of lactation were $(21.1 \mathrm{mg} / \mathrm{dl}, 0.88 \mathrm{mg} / \mathrm{dl}$, $4.7 \mathrm{mg} / \mathrm{dl}$ ) respectively, in the $2^{\text {nd }}$ month of lactation were $(27.8 \mathrm{mg} / \mathrm{dl}, \quad 1.01 \mathrm{mg} / \mathrm{dl}, 4.99 \mathrm{mg} / \mathrm{dl})$ respectively, in the $3^{\text {rd }}$ month of lactation were $(29$ $\mathrm{mg} / \mathrm{dl}, 1.1 \mathrm{mg} / \mathrm{dl}, 4.99 \mathrm{mg} / \mathrm{dl})$ respectively.

Some antioxidants include (GSH, SOD and CAT) were measured by using spectrophotometer, the result revealed that the mean values were $(18.4 \mathrm{mu} / \mathrm{ml}, 1.28$ $\mathrm{u} / \mathrm{ml}, 4.02 \mathrm{u} / \mathrm{I})$ respectively in animals feed on unbalanced ration, while in animals feed on balanced ration in the $1^{\text {st }}$ month of lactation were $(25.2 \mathrm{mu} / \mathrm{ml}$, $3 \mathrm{u} / \mathrm{ml}, 5.23 \mathrm{u} / \mathrm{I})$ respectively, in the $2^{\text {nd }}$ month of lactation were $(24.2 \mathrm{mu} / \mathrm{ml}, 2.2 \mathrm{u} / \mathrm{ml}, 4.7 \mathrm{u} / \mathrm{I})$ respectively, in the $3^{\text {rd }}$ month of lactation were (20.9 $\mathrm{mu} / \mathrm{ml}, 1.6 \mathrm{u} / \mathrm{ml}, 4.19 \mathrm{u} / \mathrm{I})$ respectively.
The result of Glucose by using spectrophotometer revealed that the mean value was $(40.6 \mathrm{mg} / \mathrm{dl})$ in animals feed on unbalanced ration, while in animals feed on balanced ration in the $1^{\text {st }}$ month of lactation was $(48 \mathrm{mg} / \mathrm{dl})$, in the $2^{\text {nd }}$ month of lactation was $(43.8 \mathrm{mg} / \mathrm{dl})$, in the $3^{\text {rd }}$ month of lactation was $(42.1$ $\mathrm{mg} / \mathrm{dl})$.

Minerals include (Calcium, Phosphorus, Potassium, Chloride and Sodium) measured by using atomic absorption, the result revealed that the mean values were $(8.9 \mathrm{mg} / \mathrm{dl}, 4.75 \mathrm{mg} / \mathrm{dl}, 3.24 \mathrm{~m} \mathrm{~mol} / \mathrm{ml}, 96.5 \mathrm{~m}$ $\mathrm{mol} / \mathrm{I}, 119.6 \mathrm{~m} \mathrm{~mol} / \mathrm{I})$ respectively in animals feed on unbalanced ration, while in animals feed on balanced ration in the $1^{\text {st }}$ month of lactation were $(10.56 \mathrm{mg} / \mathrm{dl}$, $5.8 \mathrm{mg} / \mathrm{dl}, 4.07 \mathrm{~m} \mathrm{~mol} / \mathrm{ml}, 134.3 \mathrm{~m} \mathrm{~mol} / \mathrm{I}, 141 \mathrm{~m}$ mol/I) respectively, in the $2^{\text {nd }}$ month of lactation were (9.84 mg/dl, $5.44 \mathrm{mg} / \mathrm{dl}, 3.43 \mathrm{~m} \mathrm{~mol} / \mathrm{ml}, 125.7 \mathrm{~m}$ mol/I, $129.3 \mathrm{~m} \mathrm{~mol} / \mathrm{I})$ respectively, in the $3^{\text {rd }}$ month of lactation were $(9.05 \mathrm{mg} / \mathrm{dl}, 4.87 \mathrm{mg} / \mathrm{dl}, 3.05 \mathrm{~m}$ $\mathrm{mol} / \mathrm{ml}, 117.9 \mathrm{~m} \mathrm{~mol} / \mathrm{I}, 114.2 \mathrm{~m} \mathrm{~mol} / \mathrm{I})$ respectively.

The result of Cupper, Iron and Selenium revealed that the mean values were $(63.5 \mathrm{mg} / \mathrm{dl}, 160.6 \mathrm{mg} / \mathrm{dl}, 0$ $\mathrm{ug} / \mathrm{dl})$ respectively in animals feed on unbalanced ration, while in animals feed on balanced ration in the $1^{\text {st }}$ month of lactation were $(92 \mathrm{mg} / \mathrm{dl}, 196.8$ $\mathrm{mg} / \mathrm{dl}, 0.58 \mathrm{ug} / \mathrm{dl})$ respectively, in the $2^{\text {nd }}$ month of lactation were $(96.7 \mathrm{mg} / \mathrm{dl}, 214.2 \mathrm{mg} / \mathrm{dl}, 0.196 \mathrm{ug} / \mathrm{dl})$ respectively, in the $3^{\text {rd }}$ month of lactation were (104.2 $\mathrm{mg} / \mathrm{dl}, 186.5 \mathrm{mg} / \mathrm{dl}, 0.157 \mathrm{ug} / \mathrm{dl}$ ) respectively, also we measured (lead and cadmium) and obtained no data in both unbalanced and balanced rations.

The result of TSH in serum and Leptin in milk by using ELISA revealed that the mean values were (2.4, 7.6) respectively in animals feed on unbalanced ration, while in animals feed on balanced ration in the $1^{\text {st }}$ month of lactation were $(2.8,9.6)$ respectively, in the $2^{\text {nd }}$ month of lactation were $(2.7,12.7)$ respectively, in the $3^{\text {rd }}$ month of lactation were $(3.4$, 13.4) respectively.

Finally, Insulin measured by using ELISA, the result revealed that the mean value was $(13.8 \mathrm{mg} / \mathrm{dl})$ in animals feed on unbalanced ration, while in animals feed on balanced ration in the $1^{\text {st }}$ month of lactation was $(10 \mathrm{mg} / \mathrm{dl})$, in the $2^{\text {nd }}$ month of lactation was $(12.7 \mathrm{mg} / \mathrm{dl})$, in the $3^{\text {rd }}$ month of lactation was $(13.77$ $\mathrm{mg} / \mathrm{dl})$. 
All these results showed in table (3).

Table 3: Effect of lactation stages on different parameters.

\begin{tabular}{|c|c|c|c|c|}
\hline \multirow{2}{*}{$\begin{array}{c}\text { Parameters } \\
(\mathbf{X}- \pm \text { SD })\end{array}$} & \multirow{2}{*}{$\begin{array}{c}\text { Animals feed on } \\
\text { on unbalanced ration } \\
\text { (A) }\end{array}$} & \multicolumn{3}{|c|}{ Animals feed on balanced ration } \\
\hline & & 1 st month (B) & $\begin{array}{l}2 \text { nd month } \\
\text { (C) }\end{array}$ & 3 rd month (D) \\
\hline Insulin (mg/dl) & $13.8 \pm 0.53$ & $10 \pm 0.25^{\mathrm{AB} *}$ & $12.7 \pm 0.38 *$ & $13.77 \pm 0.47 *$ \\
\hline SGOT (u/ml) & $59.2 \pm 3.01$ & $41.3 \pm 2.11^{\mathrm{AB} *}$ & $48.4 \pm 3.17 *$ & $48 \pm 1.89 *$ \\
\hline SGPT (u/ml) & $36 \pm 2.5$ & $38.6 \pm 2.46^{\mathrm{AB} *}$ & $36.3 \pm 2.7 *$ & $36.5 \pm 2.32 *$ \\
\hline $\mathbf{A L P}(\mathbf{u} / \mathbf{m l})$ & $125.9 \pm 4.41$ & $121.9 \pm 7.6$ & $123.2 \pm 6.3$ & $123.3 \pm 5.4$ \\
\hline Total bilirubin(mg/dl) & $1.02 \pm 0.056$ & $0.83 \pm 0.099^{\mathrm{AB} *}$ & $0.92 \pm 0.083 *$ & $0.84 \pm 0.089$ \\
\hline Urea $(\mathrm{mg} / \mathrm{dl})$ & $35.2 \pm 4.9$ & $21.1 \pm 3.57^{\mathrm{AB} *}$ & $27.8 \pm 2.57 *$ & $29 \pm 3.16^{*}$ \\
\hline Creatinine (mg/dl) & $1.19 \pm 0.12$ & $0.88 \pm 0.11^{\mathrm{AB} *}$ & $1.01 \pm 0.99 *$ & $1.1 \pm 0.062 *$ \\
\hline Uric acid (mg/dl) & $4.99 \pm 0.63$ & $4.7 \pm 0.51$ & $4.99 \pm 0.17$ & $4.99 \pm 0.36$ \\
\hline Calcium (mg/dl) & $8.9 \pm 0.2$ & $10.56 \pm 0.53^{\mathrm{AB} *}$ & $9.84 \pm 0.28 *$ & $9.05 \pm 0.34 *$ \\
\hline Phosphorus (mg/dl) & $4.75 \pm 0.26$ & $5.8 \pm 0.15^{\mathrm{AB} *}$ & $5.44 \pm 0.36^{*}$ & $4.87 \pm 0.12^{*}$ \\
\hline Potassium (mmol/ml) & $3.24 \pm 0.18$ & $4.07 \pm 0.37^{\mathrm{AB} *}$ & $3.43 \pm 0.25^{*}$ & $3.05 \pm 0.09 *$ \\
\hline Chloride (mmol/l) & $96.5 \pm 4.43$ & $134.3 \pm 5.7^{\mathrm{AB} *}$ & $125.7 \pm 3.8^{*}$ & $117.9 \pm 5.49 *$ \\
\hline Sodium (mmol/l) & $119.6 \pm 1.96$ & $141 \pm 2.44^{\mathrm{AB} *}$ & $129.3 \pm 1.8^{*}$ & $114.2 \pm 4.19 *$ \\
\hline Cupper (mg/dl) & $63.5 \pm 4.5$ & $92 \pm 5.2^{\mathrm{AB} *}$ & $96.7 \pm 2.2 *$ & $104.2 \pm 4.5 *$ \\
\hline Iron (mg/dl) & $160.6 \pm 12.7$ & $196.8 \pm 7.8^{\mathrm{AB} *}$ & $214.2 \pm 6.68^{*}$ & $186.5 \pm 10.3^{*}$ \\
\hline Selenium (ug/dl) & $\begin{array}{l}----- \\
\end{array}$ & $0.58 \pm 0.32^{\mathrm{AB} *}$ & $0.196 \pm 0.07 *$ & $0.157 \pm 0.04 *$ \\
\hline GSH(mu/ml) & $18.4 \pm 1.3$ & $25.2 \pm 2.6^{\mathrm{AB} *}$ & $24.2 \pm 2.5^{*}$ & $20.9 \pm 1.52 *$ \\
\hline SOD $(\mathbf{u} / \mathbf{m l})$ & $1.28 \pm 0.13$ & $3 \pm 0.4^{\mathrm{AB} *}$ & $2.2 \pm 0.14 *$ & $1.6 \pm 0.32 *$ \\
\hline CAT(u/l) & $4.02 \pm 0.14$ & $5.23 \pm 0.20^{\mathrm{AB} *}$ & $4.7 \pm 0.19^{*}$ & $4.19 \pm 0.18^{*}$ \\
\hline Leptin & $7.6 \pm 0.5$ & $9.6 \pm 0.72^{\mathrm{AB} *}$ & $12.7 \pm 0.8^{*}$ & $13.4 \pm 0.53^{*}$ \\
\hline TSH & $2.4 \pm 0.35$ & $2.8 \pm 0.7$ & $2.7 \pm 0.5$ & $3.4 \pm 0.4^{*}$ \\
\hline Glucose (mg/dl) & $40.6 \pm 1.5$ & $48 \pm 2.5^{\mathrm{AB} *}$ & $43.8 \pm 1.9^{*}$ & $42.1 \pm 2.13^{*}$ \\
\hline
\end{tabular}

\section{DISCUSSION}

The lactation phase affects significantly the metabolic profile and so the variation recorded during this phase is expected. The lactation phase is a period of great metabolic stress for dairy cows (Rollin et al., 2010).

There was a significant increment in insulin level of second and third month of lactation groups when compared to first month of lactation group, this observation may be attributed to the effect of high concentrate diet is at long term and very small in the early lactation (Campanile et al., 1995). These results agreed with that reported by (Fiore et al., 2014 and 2018) and disagreed with that reported by (Accorsi et al., 2005).

There was a significant increment in SGOT and ALP levels of second and third months of lactating animals when compared to its level in the first month of lactating group while, there was a decrement in the level of SGPT in second and third months when compared to the first month of lactation, this change following physiological or pathological conditions. These results agreed with that reported by (Nozed et al., 2014 and Khan et al., 2016) and disagreed with (Jozwik et al., 2012).

There was non-significant change in total bilirubin level of the third month of lactation groups when compared to first month of lactation group while, in the second month its level increased, this observation may be due to physical stress. These results agreed with that reported by (Piccione et al., 2012).

There was a significant increment in urea level of second and third month of lactation groups when compared to first month of lactation group, this observation may be attributed to the fact that increased deamination or increased protein intake in dairy animals (Roubies et al., 2006). These results agreed with that reported by (Eman et al., 2014 and Fiore et al., 2018) and disagreed with that recorded by (Accrosi et al., 2005 and Piccione et al., 2012).

There was a significant increment in creatinine level of second and third month of lactation groups when compared to first month of lactation group. These results disagreed with that reported by (Piccione et al., 2012).

There was non- significant decrement in uric acid level of second and third month of lactation groups when compared to first month of lactation group, these results may attributed to oxidative stress in dairy cows. These results agreed with that reported by (Pienta et al., 2006).

There was a significant decrement incalcium, chloride, sodium, potassium and phosphorus levels of 
second and third month of lactation groups when compared to first month of lactation group. These results may attributed to physiological status of lactating animals and the high production of milk in the second and third month of lactation in compared to the first month as reported by (Cozzi et al., 2011). The results of chloride, sodium, potassium and phosphorus notagreed withthat reported by (Nozad et al., 2014) and the results of both chloride and calcium agreed with that recorded by (Hussien et al., 2001).

There was a significant increment in cupper level of second and third month of lactation groups when compared to first month of lactation group.

There was a significant increment in iron level of second month of lactation groups when compared to first month of lactation group while, there was a decrement in iron level in third month of lactation when compared to the first and second month of lactation. These results not agreed with that reported by (Hussien et al., 2001).

There were no data obtained for lead and cadmium in our balanced and un balanced rations. These results may attributed to the healthy environment in which the both healthy and control groups reared.

There was a significant decrement in selenium level of second and third month of lactation groups when compared to first month of lactation group. These results may attributed to the transfer of Se from the blood to the milk produced largely in peak lactation, these results not agreed with that reported by (Jana et al., 2015) and agreed with that recorded by (Cong and Xiao, 2016).

There was a significant decrement in SOD, GSH and CAT levels of second and third month of lactation groups when compared to first month of lactation group, these results may be due to oxidative stress. These results agreed with that reported by (Bernabucci et al., 2002 and Jana et al., 2015) and disagreed with that reported by (Iulia et al., 2012).

There was a significant increment in leptin hormone level of second and third month of lactation groups when compared to first month of lactation group, increasing leptin concentration in milk with time the advancement of lactation. These results agreed with that reported by (Ashmawy, 2015) and disagreed with that reported by (Accrosi, 2005).

There was a significant decrement in TSH level of first and second month of lactation groups when compared to third month of lactation group, these results suggesting a possible role of thyroid gland on the start of lacto genesis. These results agreed with that reported by (Fiore et al., 2018).
There was a significant decrement in glucose level of second and third month of lactation groups when compared to first month of lactation group, these results may lead to over production of ketones. These results disagreed with that reported by (Hagwane et al., 2009 and Kalasariya et al., 2017).

In addition, there were variations between the levels of all parameters except ALP, uric acid and TSH in healthy animals when compared to the hazard control ones that may attributed to the differences in ration.

\section{REFERANCES:}

Abdulkareem, T.A. (2013): Some hematological and blood biochemical attributes of Iraqi riverine buffaloes (Bubalusbubalis) around calving and postpartum periods. Al-Anbar J. Vet. Sci., Vol., 6 (1):143-150.

A.O.A.C. (2015): Official method of analysis. AOAC Int. Anlington, VA.

Accorsi, P.A.; Govoni, N.; Gaiani, R.; Pezzi, C.; Seren, E. and Tamanini, C. (2005): Leptin, $\mathrm{GH}, \mathrm{PRL}$, Insulin and metabolic parameters throughout the dry period and lactation in dairy cows. Reprod Dom Anim. Vol., 40: 217-223.

Arfuso, F.; Fazio, F.; Levanti, M.; Rizzo, M.; Di Pietro, S. and Giudice, E. (2016): Lipid and lipoprotein profile changes in dairy cows in response to late pregnancy and the early postpartum period. Archives Animal Breeding. Vol., 59: 429 \pm 34 .

Ashmawy, N.A. (2015): Changes in peripheral plasma hormone concentrations and metabolites during the last trimester of pregnancy and around parturition in the Egyptian buffalo and Baladi cows. International Journal of Advanced Research. Vol., 3: 1377 \pm 90 .

Bernabucci, U.; Ronchi, B.; Lacetera, N. and Nardone, A. (2002): Markers of oxidative status in plasma and erythrocytes of transition dairy cows during hot season. J. Dairy Sci. Vol., 85: 2173-2179.

Campanile, G.; Di Palo, R.; Esposito, L.; Boni, R. and Di Meo, C. (1995): Variazioni di alcunecostantiematiche in bufale in lattazione. In: Proceedings of the 11th National Congress A.S.P.A. 19-22 June, Grado (GO), Italia. Pp.77-78.

Cong, J. and Xiao, M. (2016): Selenium and antioxidant status in dairy cows at different stages of lactation. Biol Trace Elem Res. Vol., 171: 89-93.

Cozzi, G.; Ravarotto, L.; Gottardo, F.; Stefani, AL.; Contiero, B.; Moro, L.; Brscic, M. and Dalvit, P. (2011): Reference values for blood parameters in Holstein dairy cows: effects of parity, stage of lactation, and season of production. J Dairy Sci. Vol., 94:3895-3901. 
Eman, M.A.; Ghada, A.E.M. and Hanan, K.E. (2014): Effect of lactation stages on some blood serum biochemical parametersand milk composition in dairy cows. Assiut Vet. Med. J. Vol. 60 (142): 83-88.

FAO. (2009): Food Outlook, Global Market Analysis.42-51.

Fiore, E.; Gianesella, M.; Arfuso, F.; Giudice, E.; Giuseppe, P.; Loral, M.; Stefani, A. and Morgante, M. (2014): Glucose infusion response to some biochemical parameters in dairy cows during the transition period. Archiv Tierzucht. Vol., 57(3): 1-9.

Fiore, E.; Giambelluca, S.; Morgante, M.; Contiero, B.; Mazzotta, E.; Vecchio, D.; Vazzana, I.; Rossi, P.; Arfuso, F.; Piccione, G. and Gianesella, M. (2018): Changes in some blood parameters, milk composition and yield of buffaloes (Bubalusbubalis) during the transition period. Animal Science Journal, PP.1-8.

Hagawane, S.D.; Shinde, S.B. and Rajguru, D.N. (2009): Haematological and Blood Biochemical Profile in Lactating Buffaloes in and around Parbhani city Veterinary World, Vol.2 (12): 467-469.

Hussain, S.; Amir, M. and Nazli, I. (2001): Serum electrolytes in buffaloes during late pregnancy, parturition and postpartum period.Pakistan Vet. J. Vol., 21(4): 175-179.

Iulia, F.; Vioara, M.; Camelia, R.; Daniel, C.; Radu, C. and Aurelia, C. (2012): Evaluation of oxidative stress in dairy cows through antioxidant enzymes glutathione peroxidase (GPX) and superoxide dismutase (SOD). Bulletin UASVM Animal Science and Biotechnologies. Vol., 69: 1-2.

Jana, K.; Mária, V.; Iveta, P.; Gabriel, K. and Zuzana, K. (2015): Oxidative stress and antioxidant status in dairy cows during prepartal and postpartal periods. ACTA VET. BRNO. Vol., 84: 133-140.

Joźwik, A.; Strzałkowska, N.; Bagnicka, E.; Grzybek, W.; Krzyżewski, J.; Poławska, E.; Kołataj, A.; and Horbańczuk, J.O. (2012): Relationship between milk yield, stage of lactation, and some blood serum metabolic parameters of dairycows. Czech J. Anim. Sci. Vol., 57 (8): 353-360.

Kalasariya, R.M.; Dhami, A.J.; Hadiya, K.K.; Borkhatariya, D.N. and Patel, J.A. (2017): Effect of peripartum nutritional management on plasma profile of steroid hormones, metabolites, and postpartum fertility in buffaloes. Veterinary World. Vol., 10: 302310.

Khan, A.; Mohammed, A.; Samaroo, J.; Edwards, A.; Bridgemohan, P.; Sieuchand, S. and Perry, G.
(2016): Preliminary observations on changes in blood metabolite concentrations in early lactation in lactating buffaloes compared with open buffaloes. International Journal of Agriculture and Environmental Research. Vol., 2 (3): 447-454.

Nozad, S.; Ramin, A.G.; Moghaddam, G.; AsriRezaei, S. and Kalantary, L. (2014): Monthly evaluation of blood hematological, biochemical, mineral, and enzyme parameters during the lactation periodin Holstein dairy cows. Comp ClinPathol. Vol., 23: 275-281.

Piccione, G.; Vanessa, M.; Simona, M.; Stefania, C. and Claudia, G. (2012): Changes of some haematochemical parameters in dairy cows during late gestation, post- partum, lactation and dry periods. Vet Med Zoot. T. Vol., 58 (80): 59-64.

Pintea, A.; Daniela, Z.; Rai, P.; Sanda, A. and Ervin, $K$. (2006): Antioxidant status in dairy cows during lactation.Buletin USAMV-CN. Vol., 63: 130-135.

Rollin, E.; Berghaus, R.D.; Rapnicki, P.; Godden, S.M. and Overton, M.W. (2010): The effect of injectable butaphosphan and cyanocobalamin on postpartum serum b Hydroxybutyrate, calcium and phosphorus concentrations in dairy cattle.Journal of Dairy Science. Vol., 93: 978-987.

Roubies, N.; Panouis, N.; Fytianou, A.; Katsoulos, P.D.; Giadinis, N. and Karatzias, H. (2006): Effects of age and reproductive stage on certain serum biochemical parameters of Chios sheep under greek rearing conditions. J. Vet. Med. A, T. Vol., 53: 277-281.

Samardzjia, M.; Dobranic, T.; Lipar, M.; Harapin, I.; Prvanovic, N.; Girzelji, J.; GreguricGracner, G.; Dobranic, V.; Radisic, B. and Duricic, D. (2011): Comparison of blood serum acromineral concentrations in meat and dairy goats during puerperium. VeterinarskiAhriv. T. 81. P. 1-11.

Sarwar, M.; Khan, M.A.; Nisa, M.; Bhatti, S.A. and Shahazd, M.A. (2009): Nutritionalmanagement for buffalo production. Asian Aust. J. Anim. Sci., 22: 1060-1068.

Sendecor, G.W. and Cochran, W.G. (1980): Statistical Method. $7^{\text {th }}$ ed., Iowa State Univ. Press, Ames, Iowa, USA.

Smith, B.I. and Risco, C.A. (2005): Management of periparturient disorders in dairy cattle. Vet Clin North Am Food Anim Pract. Vol., 21: 503-521.

Yaylak, E.; Yenisey, C. and Seyrek, K. (2009): Effects of lameness, stage of lactation and body condition score on some blood parameters in Holstein cows. Asian J. Anim. Vet. Adv. Vol., 4(5): 245-251. 


\section{صورة المؤشرات الكيموحيوية في مصل دم الابقار اثناء فترة الحليب \\ شبياء عبله عبل الرحبي ، حسن بيوسف عبل الحمبإ ، محمود محد عرفه ، عادل السبإ أحدا \\ E-mail: adel.mohamed@vet.svu.edu.eg Assiut University web-site: www.aun.edu.eg}

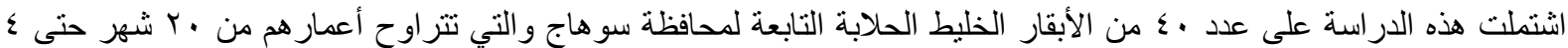

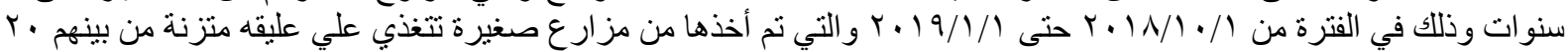

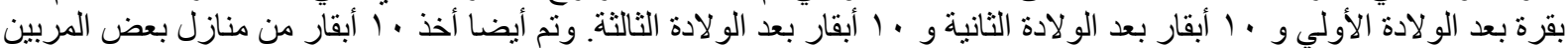

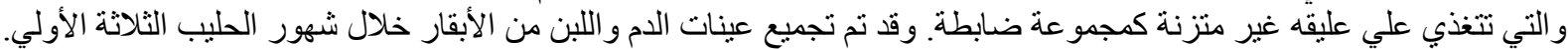

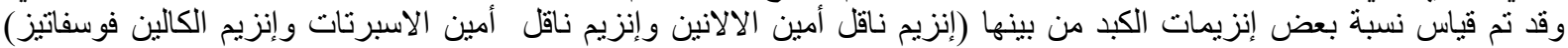

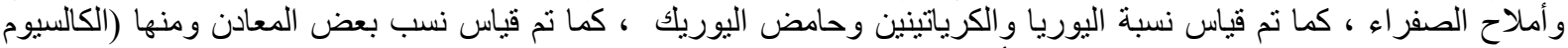

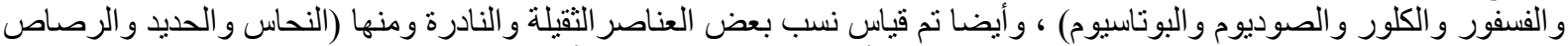

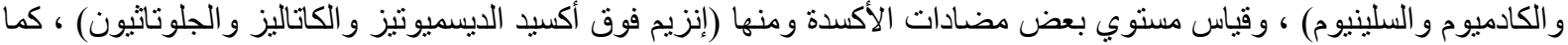

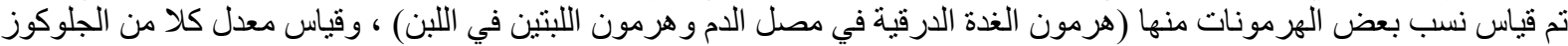

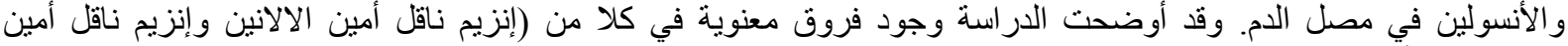

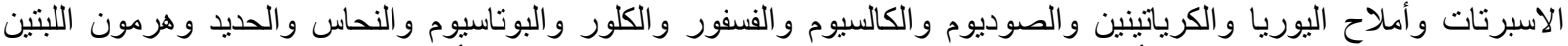

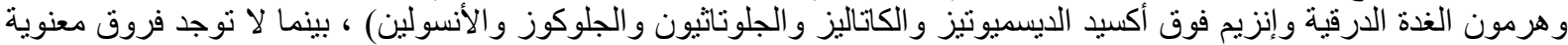

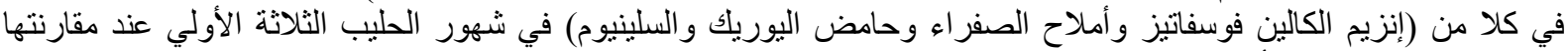

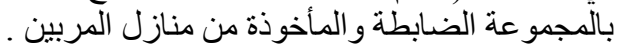

